\title{
Estudo taxonômico da Tribo Cassieae (Leguminosae - Caesalpinioideae) no Parque Ecológico Engenheiro Ávidos, Cajazeiras-PB
}

\author{
Flávio Sousa Souto ${ }^{1,2} \mathbb{D}$, Aclébia Alves Quaresma ${ }^{1,2} \mathbb{D}$, Rubens Teixeira de \\ Queiroz $^{3,4} \&$ Maria do Socorro Pereira ${ }^{1}$
}

(1) Universidade Federal de Campina Grande, Centro de Formação de Professores, Unidade Acadêmica de Ciências Exatas e da Natureza, Rua Sérgio Moreira de Figueiredo, Casas Populares 58900-000, Cajazeiras, Paraíba, Brasil. E-mail: mspereira@ufcg.edu.br, aclebialves@gmail.com

(2) Universidade Federal de Pernambuco, Centro de Ciências Biológicas, Departamento de Botânica, Programa de Pós-Graduação em Biologia Vegetal, Avenida Professor Moraes Rego 1235, Cidade Universitária 50670-901, Recife, Pernambuco, Brasil. E-mail: flaviosoutobio@gmail.com

(3) Universidade Federal da Paraíba - Campus I, Centro de Ciências Exatas e da Natureza, Departamento de Sistemática e Ecologia, Jardim Universitária, Castelo Branco 58051-900, João Pessoa, Paraíba, Brasil. E-mail: rbotanico@gmail.com

(4) Universidade Federal da Paraíba - Campus I, Centro de Ciências Exatas e da Natureza, Mestrado Profissional em Ensino de Biologia, Cidade Universitária 58051-900, João Pessoa, Paraíba, Brasil.

Souto F.S., Quaresma A.A., Queiroz R.T. \& Pereira M.S. (2019) Estudo taxonômico da Tribo Cassieae (Leguminosae - Caesalpinioideae) no Parque Ecológico Engenheiro Ávidos, Cajazeiras-PB. Pesquisa e Ensino em Ciências Exatas e da Natureza, 3(1): 18-39. http://dx.doi.org/10.29215/pecen.v3i1.1146

Editora acadêmica: Marla Ibrahim Uehbe de Oliveira. Recebido: 22 Outubro 2018. Aceito: 28 Dezembro 2018. Publicado: 27 Maio 2019.

Resumo: Este trabalho consiste no estudo taxonômico da Tribo Cassieae no Parque Ecológico Engenheiro Ávidos, Cajazeiras - Paraíba, realizado entre fevereiro/2017 a abril/2018. Foram registrados na área, 12 espécies, distribuídas em dois gêneros: Chamaecrista (6) e Senna (6). Dentre as espécies encontradas, destacam-se Chamaecrista pilosa, aqui citada como novo registro para o estado da Paraíba e as ocorrências de $C$. amiciella e $C$. duckeana, espécies endêmicas da Caatinga. Apresenta-se chave analítica para identificação das espécies, descrições morfológicas e informações complementares. Nesse contexto, evidencia-se a relevante contribuição deste estudo para o conhecimento da flora na região.

Palavras chave: Caatinga, diversidade florística, Taxonomia vegetal, Fabaceae.

Taxonomic study of the Tribe Cassieae (Leguminosae - Caesalpinioideae) in the Engenheiro Ávidos Ecological Park, Cajazeiras-PB

Abstract: This work consists in a taxonomic study of the Tribe Cassieae in the Engenheiro Ávidos Ecological Park, Cajazeiras - Paraíba, carried out between February/2017 an April/2018. Twelve species were recorded in the area, distributed in two genera: Chamaecrista (6) and Senna (6). Among the species found, we highlight Chamaecrista pilosa, here cited as a new registry for the state of Paraíba and the occurrences of $C$. amiciella and $C$. duckeana, endemic species of the Caatinga. Analytical key for species identification, morphological descriptions and complementary information are presented. In this context, the relevant contribution of this study to the knowledge of the flora in the region is evidenced.

Key words: Caatinga, floristic diversity, plant Taxonomy, Fabaceae.

\section{Introdução}

Leguminosae Juss. tem distribuição cosmopolita, sendo mais diversa nas regiões tropicais e subtropicais, ocorrendo em variados hábitats e estratos vegetacionais (Lewis et al. 
2005; Queiroz 2009). Esta família com 19.500 espécies e 765 gêneros é a terceira maior em número de espécies dentre as Angiospermas, superada apenas por Asteraceae e Orchidaceae (Lewis et al. 2005; LPWG 2017). No Brasil são registrados, aproximadamente, 222 gêneros e 2.848 espécies. Além disso, seus táxons apresentam alta diversidade na Caatinga, estando constituída por 128 gêneros e 613 espécies, das quais 144 são endêmicas e 202 referidas para o estado da Paraíba (Cardoso \& Queiroz 2007; Flora do Brasil 2020 em construção).

$\mathrm{Na}$ antiga classificação, Leguminosae era constituída por três subfamílias: Caesalpinioideae DC., Mimosoideae DC. e Papilionoideae DC. (Lewis et al. 2005; LPWG 2013). No entanto, foi constatada a parafilia em Caesalpinioideae, evidenciada em análises de sequências de genes e plastídios, sendo corroboradas por estudos recentes desenvolvidos pelo The Legume Phylogeny Working Group (LPWG). Assim, a família encontra-se circunscrita em seis subfamílias: Cercidoideae LPWG, Detarioideae Burmeist., Dialioideae LPWG, Duparquetioideae LPWG, Papilionoideae DC. e Caesalpinioideae DC. (incluindo o Clado Mimosoideae) (LPWG 2017).

Dentre as Caesalpinioideae, a Tribo Cassieae Bronn. aparece como polifilética, abrangendo 21 gêneros e 721 espécies. Destes, Cassia L., Chamaecrista Moench e Senna Mill. são amplamente distribuídos em vários tipos de ambientes, sendo facilmente reconhecidos pela combinação dos caracteres: árvores, arbustos ou ervas, de folhas compostas, nectários extraflorais no pecíolo, entre os folíolos ou ausentes, corola amarela, comumente assimétrica, estames heterodínamos, anteras basifixas, deiscência comumente poricida e fruto do tipo legume (Irwin \& Barneby 1982; Lewis et al. 2005; Queiroz 2009).

Vale ressaltar que o grupo é rico também em regiões semiáridas, de paisagens variadas, com fitofisionomias e composição florística diferenciadas (Queiroz 2009). Em função da relevância dessa cobertura vegetal, procurou-se elucidar as lacunas do conhecimento sobre a flora da Caatinga no Sertão Paraibano, especialmente dos representantes da família Leguminosae na região. Desta forma, foi realizado um estudo taxonômico das espécies da Tribo Cassieae no Parque Ecológico Engenheiro Ávidos, visando contribuir para a ampliação dos dados florísticos em áreas remanescentes de vegetação nativa no estado.

\section{Material e Métodos}

\section{Área de estudo}

O Parque Ecológico Engenheiro Ávidos (PECEA), criado em 08 de agosto de 1997, através da Lei Orgânica Municipal, Título V, art. 236, § I, do Anteprojeto de Lei No 25/97, está inserido na mesorregião do Sertão Paraibano, abrangendo os municípios de Cajazeiras e São José de Piranhas (Figura 1). Em termos climatológicos, as temperaturas variam de 23 a $33^{\circ} \mathrm{C}$, e a precipitação média é de $800 \mathrm{~mm}$. As chuvas são mais concentradas de fevereiro a abril, e estiagem prolongada nos demais meses do ano, o que influencia diretamente na composição da cobertura vegetal (Feitosa 2000).

O solo é raso com composição arenoso-argilosa na base da serra e no platô argilosopedregoso, onde ocorrem afloramentos rochosos (Figura 2A-B). Constantemente suscetível a erosão, é considerado de média a alta fertilidade (Figura 2C) (Bandeira 2016). A fitofisionomia típica é de Caatinga hiperxerófila, com formações arbóreas fechadas e espécies de grande porte nos pontos mais altos. Já o estrato arbustivo-herbáceo se dá em todos os ambientes do Parque, em especial durante o período chuvoso (Freitas 2012). O PECEA é formado por ecossistemas aquáticos, representados pela barragem Engenheiro Ávidos (Figura 2D) e córregos, e de terrestres, constituídos pela vegetação nativa, áreas agricultáveis, com perturbações constantes, causadas por ações antrópicas (Figura 2E-F) (Feitosa et al. 2002).

\section{Procedimentos de Campo e de Laboratório}

Coletas de amostras férteis ocorreram mensalmente de fevereiro de 2017 a abril de 2018, sendo intensificadas na estação chuvosa. O material foi conservado em álcool $70 \%$ para posterior 
análise em laboratório e elaboração das descrições morfológicas. Foram feitas anotações em campo sobre: hábito, solo, local de coleta, frequência e visitantes florais. A herborização seguiu as técnicas usuais em taxonomia vegetal, tal como descreve Gadelha-Neto et al. (2013), com amostras depositadas no acervo do Herbário Lauro Pires Xavier (JPB). Foram, ainda, analisadas amostras depositadas no JPB. Neste estudo, adotou-se a proposta de classificação para a família Leguminosae do The Legume Phylogeny Working Group (LPWG 2017).
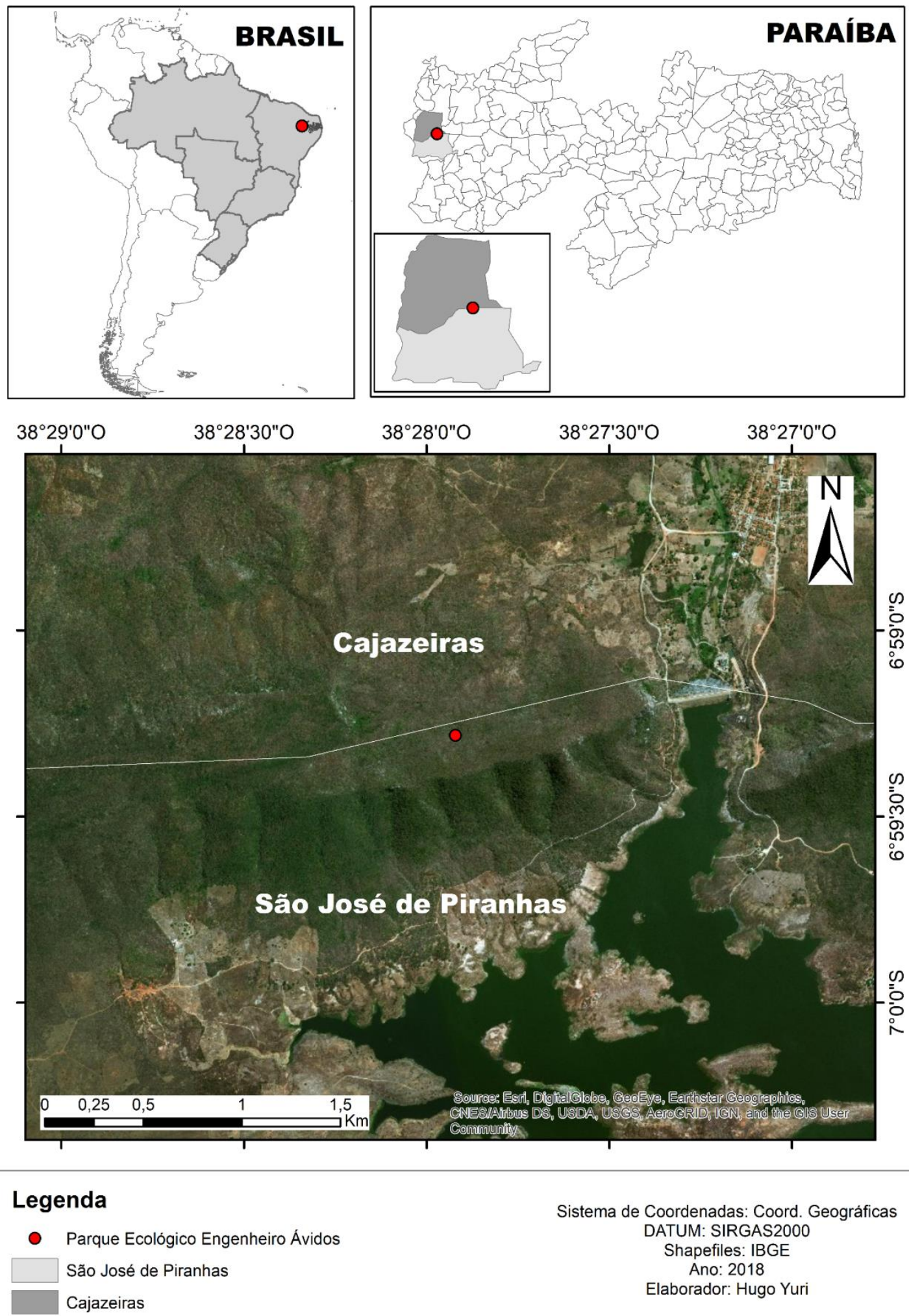

- Parque Ecológico Engenheiro Ávidos São José de Piranhas Cajazeiras

Sistema de Coordenadas: Coord. Geográficas DATUM: SIRGAS2000 Shapefiles: IBGE Ano: 2018 Elaborador: Hugo Yuri

Figura 1. Mapa de localização do Parque Ecológico Engenheiro Ávidos. 


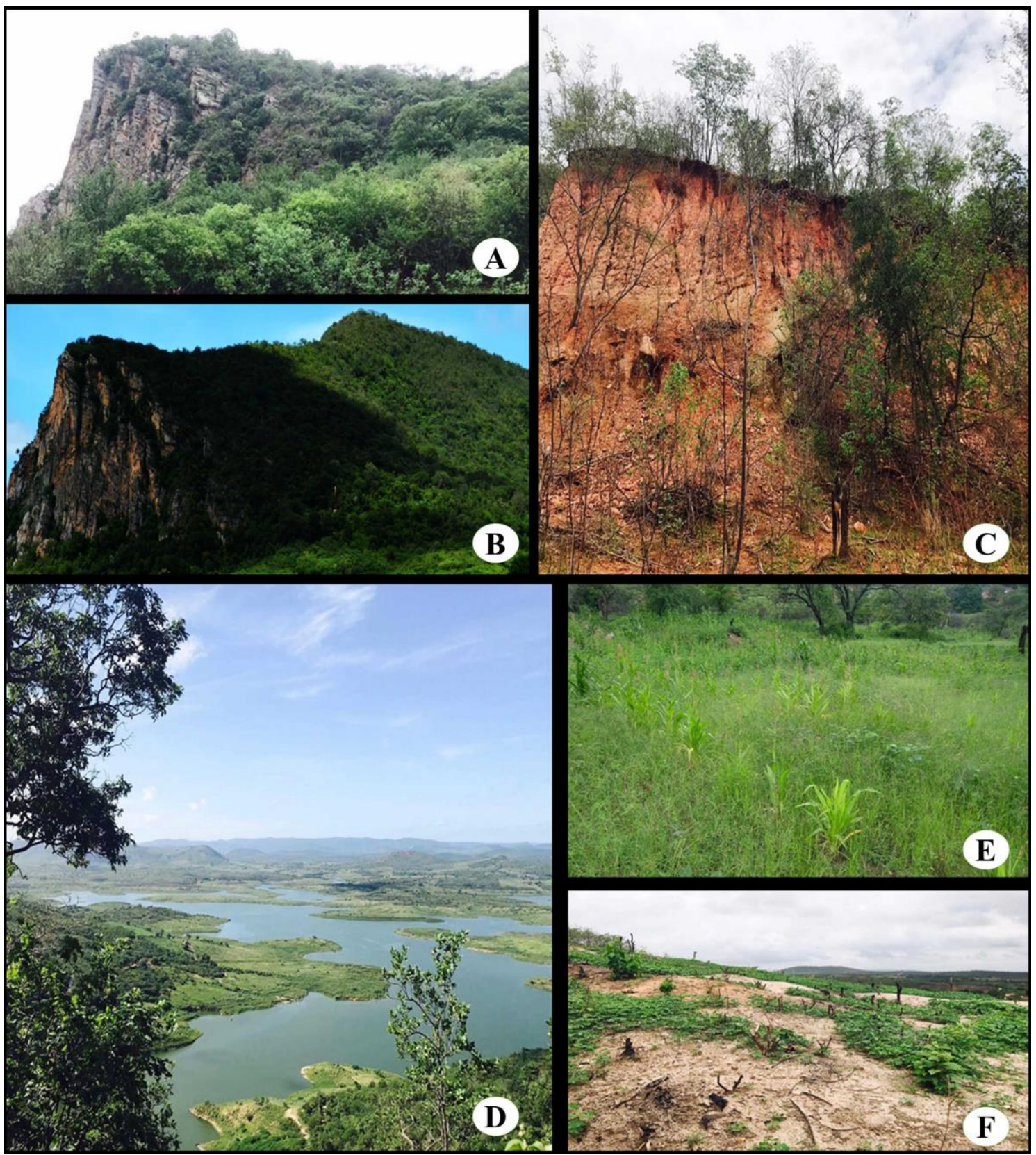

Figura 2. Parque Ecológico Engenheiro Ávidos. A. Vista frontal da serra que compõe o PECEA, B. Afloramentos rochosos, C. Erosão do solo, D. Barragem Engenheiro Ávidos, E. Plantações agrícolas, F. Ações antrópicas.

As descrições morfológicas foram elaboradas no Laboratório de Botânica do Centro de Formação de Professores da Universidade Federal de Campina Grande, com o auxílio de estereomicroscópio binocular e paquímetro, seguindo as bibliografias: Spjut (1994), Vidal \& Vidal (2003), Souza et al. (2013) e Gonçalves \& Lorenzi (2011). As identificações basearam-se no referencial teórico (Irwin \& Barneby 1982; Queiroz 2009; Queiroz \& Loiola 2009; Dantas \& Silva 2013; Silva \& Melo 2013; Souza \& Silva 2015; Souza \& Silva 2016; Santos et al. 2017), na análise de tipos nomenclaturais abrigados em herbários virtuais, e por fim, confirmadas por especialistas. O nome científico e abreviatura dos autores das espécies estão de acordo com Flora do Brasil 2020 (Flora do Brasil 2020 em construção).

A chave analítica foi construída a partir dos caracteres morfológicos das espécies encontradas no Parque. As descrições foram complementadas com pranchas fotográficas, dados 
de distribuição geográfica analisados para o Brasil (Flora do Brasil 2020 em construção), além de informações ecológicas, fenologia e nome popular das espécies quando conhecido.

\section{Resultados e Discussão}

Foram registradas 12 espécies pertencentes à tribo Cassieae no Parque Ecológico Engenheiro Ávidos, distribuídas em dois gêneros, sendo seis de Chamaecrista: C. amiciella (H.S. Irwin \& Barneby) H.S. Irwin \& Barneby, C. duckeana (P. Bezerra \& Afr. Fern.) H.S. Irwin \& Barneby, $C$. pilosa (L.) Greene, $C$. rotundifolia (Pers.) Greene, $C$. serpens (L.) Greene, $C$. supplex (Mart. ex Benth.) Britton \& Rose ex Britton \& Killip; e seis de Senna: $S$. alata (L.) Roxb., $S$. obtusifolia (L.) H.S. Irwin \& Barneby, S. occidentalis (L.) Link, S. siamea (Lam.) H.S. Irwin \& Barneby, S. spectabilis (DC.) H.S.Irwin \& Barneby e S. uniflora (Mill.) H.S. Irwin \& Barneby (Figura 3).

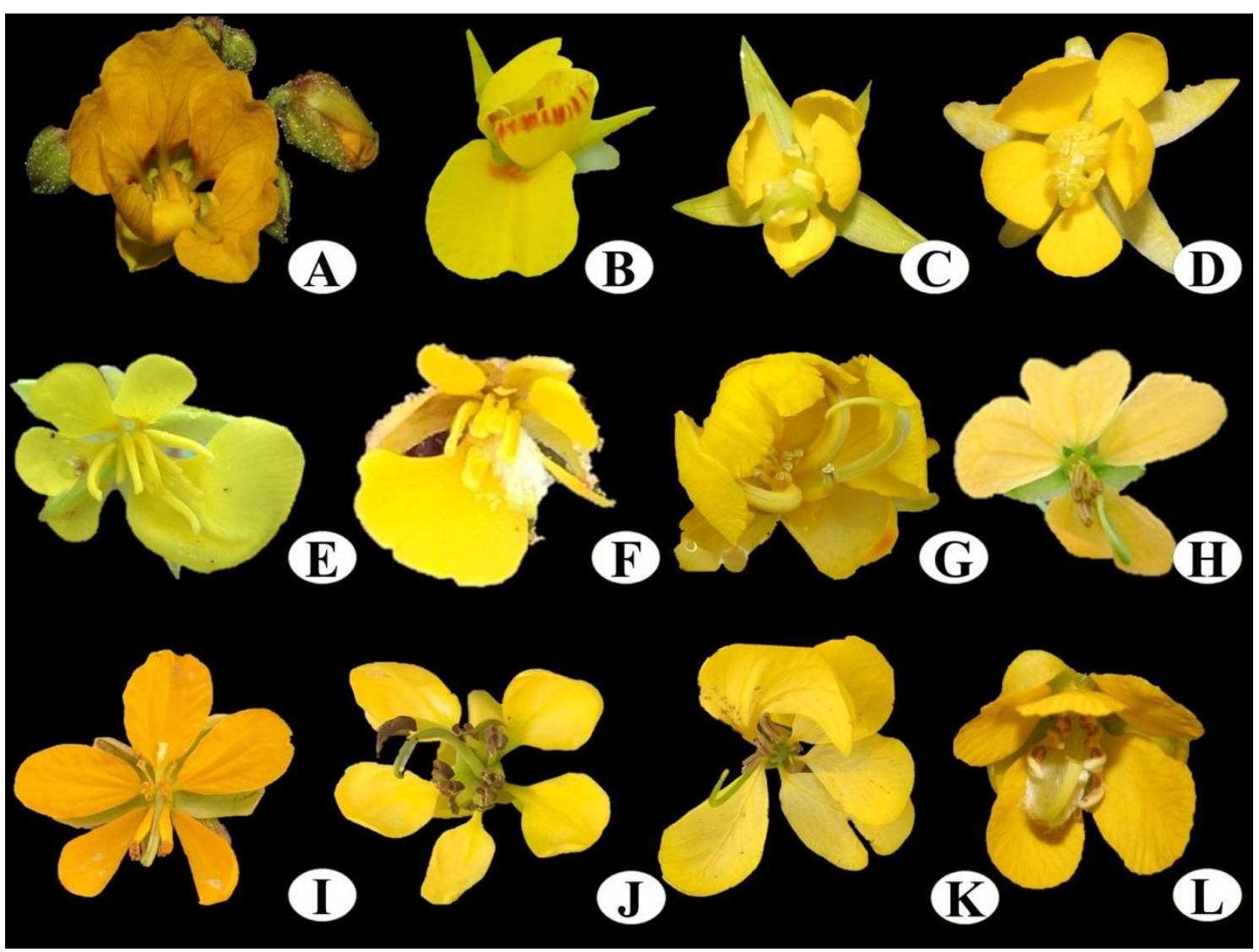

Figura 3. Espécies da Tribo Cassieae registradas no Parque Ecológico Engenheiro Ávidos: A. Chamaecrista amiciella, B. C. duckeana, G. C. pilosa, D. C. rotundifolia, E. C. serpens, F. C. supplex, G. Senna alata, H. S. obtusifolia, I. S. occidentalis, J. S. siamea, K. S. spectabilis, L. S. uniflora.

Dentre as espécies estudadas, encontram-se quatro hábitos nas seguintes proporções: ervas $33 \%$, subarbustos e arbustos $25 \%$ cada e árvores $17 \%$. Em concordância, Amorim (2014) registrou uma maior riqueza de herbáceas para a família Leguminosae na Floresta Nacional de Assú - RN. As espécies herbáceas coletadas na área são terófitas, ocorrendo na vegetação apenas na estação chuvosa, entretanto a composição deste estrato ainda é pouco conhecida (Araújo 2009).

Destaca-se ainda que, Chamaecrista pilosa trata-se de um novo registro para o estado da Paraíba. Chamaecrista amiciella e $C$. duckeana são relevantes para a flora da Caatinga por serem espécies endêmicas deste bioma (Queiroz 2009). 
Cassieae Bronn, Form. Pl. Legumin. 78, 127, 130. 1822.

Caracterização: Ervas, subarbustos, arbustos ou árvores; ramos cilíndricos glabros ou pilosos. Estípulas verdes, laterais, basifixas; caducas ou persistentes, cordiformes, lineares ou triangulares, glabras ou pilosas. Folhas alternas, compostas. Nectário extraflorais ausentes ou presentes no pecíolo ou raque. Flores isoladas ou reunidas em racemos axilares ou panículas terminais; brácteas presentes ou ausentes, caducas ou persistentes; bractéolas presentes em Chamaecrista e ausente em Senna. Flores pecioladas, zigomorfas ou assimétricas, monoclinas, hipóginas, pentâmeras; cálices dialissépalos, sépalas homomórficas ou heteromórficas, comumente verdes ou verde/amarelada; corola dialipétala, pétalas amarelas, unguiculadas, heteromórficas ou homomórficas; androceu dialistêmone, estames 5-10, homo ou heteromórficos de filetes curtos a longos, anteras poricida pelo ápice ou rimosas com suturas laterais abrindo longitudinalmente no ápice, arqueadas ou retas; gineceu unicarpelar, unilocular; ovário séssil, placentação marginal; estilete cilíndrico, comumente arqueado; estigma capitado ou globoso, glabro. Frutos legumes típicos, câmara ou baga; achatados ou cilíndricos, quadrangulares, lineares ou oblongo-lineares, valvas retas, aladas em Senna alata. Sementes oblongas, cilíndricas ou quadrangulares de cor marrom, enegrecidas ou castanhas.

\section{Chave de identificação para as espécies da Tribo Cassieae ocorrentes no Parque Ecológico Engenheiro Ávidos}

1. Nectário extrafloral ausente

2. Subarbusto ou erva; folhas 2-4-folíoladas; bractéola presente

3. Ramos com indumento híspido; folhas 2-folioladas; flores isoladas, estames 5

4. Chamaecrista rotundifolia

3'. Ramos com indumento glandular; folhas 4-folioladas; flores em racemo terminal, estames 10

1. Chamaecrista amiciella

2'. Arbusto ou árvore; folha 4-foliolada ou mais; bractéolas ausentes

4. Arbusto; brácteas petalóides presentes; legume típico com valvas aladas ....7. Senna alata

4'. Árvore; brácteas petaloides ausentes; legume típico não alado ou câmara

5. Folhas 8-22-folioladas; brácteas estreitamente triangulares; corola zigomorfa, fruto tipo legume 10. Senna siamea

5'. Folhas com 26-34-folioladas; brácteas lineares; corola assimétrica, fruto tipo câmara 11. Senna spectabilis

1'. Nectário extrafloral presente

6. Folha com 16 ou mais folíolos

7. Flores reunidas em racemos axilares reduzidos; corola com uma pétala cuculada, com manchas vermelhas no ápice, estames 10

2. Chamaecrista duckeana

7'. Flores isoladas; corola com pétalas sem manchas vermelhas, estames 5

3. Chamaecrista pilosa

6'. Folha com até 12 folíolos

8. Nectários extraflorais localizados no pecíolo, folíolos elípticos ou oblongo ou oblanceolado

9. Arbusto ereto; ramo glabrescente; folíolos elípticos, inflorescências em racemos axilares, bractéola ausente 9. Senna occidentalis

9'. Erva prostrada; ramo híspido ou hirsuto; folíolo oblongo ou oblanceolado, flores isoladas axilares, bractéola presente

10. Ramos hirsutos; pedicelo $4 \mathrm{~mm}$ compr., estames 5 ...........6. Chamaecrista supplex

10'. Ramos híspidos; pedicelo 8-10 mm compr, estames 10 ...5. Chamaecrista serpens

8'. Nectários extraflorais localizados na raque foliar, folíolos obovados

11. Ramo glabro, folha 6-foliolada, nectários exclusivamente entre o primeiro par de folíolos 8. Senna obtusifolia 
11'. Ramo velutino, folha 8-foliolada, nectários distribuídos entre todos os pares de folíolos 12. Senna uniflora

Chamaecrista Moench, Meth. Pl. Hort. Bot. Marburg: 272. 1794.

Caracterização: Subarbustos ou ervas, anuais; ramos verdes, cilíndricos, inermes. Estípulas verdes, laterais, basifixas, persistentes. Folhas alternas, compostas, bifolioladas ou paripinadas, folíolos membranáceos; nectários extraflorais ausentes ou presentes. Flores isoladas ou agrupadas em racemos axilares ou terminais; brácteas em geral ausentes; bractéolas persistentes. Flores andróginas, monoclinas, hipóginas, diclamídeas, pediceladas; cálice dialissépalo, pentâmero, sépalas verdes; corola dialipétala, pentâmera, zigomorfa ou assimétrica, pétalas amarelas, unguiculadas, obovais, glabras em ambas as faces; estames 5-10, dialistêmone, homodínamo; filetes curtos, glabros; anteras amarelas, basifixas, deiscência por duas pequenas fendas apicais, glabras ou com finos tricomas; ovário súpero, unicarpelar, unilocular, placentação marginal; estilete cilíndrico, arqueado; estigma capitado ou puntiforme, glabro. Legumes lineares ou oblongo-lineares, glabro ou piloso. Sementes com formas variadas, glabras.

Considerações: Chamaecrista abrange aproximadamente 330 espécies de distribuição Pantropical. O Brasil é o principal centro de diversidade e endemismo na América do Sul estando representado por cerca de 259 espécies, das quais 214 são endêmicas (Flora do Brasil 2020 em construção; Queiroz \& Loiola 2009). É um gênero representativo na composição da flora da Caatinga com cerca de 27 espécies, das quais as herbáceas são em geral plantas invasoras (Queiroz 2009).

1. Chamaecrista amiciella (H.S. Irwin \& Barneby) H.S. Irwin \& Barneby, Memoirs of the New York Botanical Garden 35: 661. 1982.

Figura 4A-E

Caracterização: Subarbusto, ca. $45 \mathrm{~cm}$ compr.; ramos com indumento glandular. Estípulas 2-3 $\mathrm{mm}$ compr., lineares, hirsutas. Folha $3 \mathrm{~cm}$ compr., tetrafolioladas, folíolos $10 \times 9 \mathrm{~mm}$, obovados, ápice truncado, base cuneada, margem inteira com tricomas, pubérulos em ambas as faces; pecíolo $18 \mathrm{~mm}$ compr., hirsuto, pulvino ausente, nectários extraflorais ausentes. Racemos terminais, 3-4 cm compr.; pedúnculo $3 \mathrm{~mm}$ compr., hirsuto. Flores $2.1-2.5 \mathrm{~cm}$ compr.; botões florais ovados, ápice truncado-cuneado; brácteas ausentes; bractéolas $2 \mathrm{~mm}$ compr., estreitamente triangulares, hirsuta; pedicelo $13 \mathrm{~mm}$ compr., hirsuto; cálice com sépalas medindo 6-8 $\times 3 \mathrm{~mm}$, oblongas, glabra na face adaxial e hirsuto na abaxial; corola assimétrica, pétalas 13 $\times 6 \mathrm{~mm}$, com mancha vermelha na base, sendo que a inferior envolve a androceu; estames 10, 5 $\mathrm{mm}$ compr., anteras $2 \mathrm{~mm}$ compr., oblongas; ovário $4 \mathrm{~mm}$ compr., hirsuto; estilete $9 \mathrm{~mm}$ compr., pubérulo; estigma capitado. Legumes marrons, 4.2-4.7 cm compr., lineares, tricoma glandular a híspido. Sementes enegrecidas, $4 \mathrm{~mm}$ compr.

Material examinado: BRASIL. Paraíba: Cajazeiras, Parque Ecológico Engenheiro Ávidos, Distrito Engenheiro Ávidos, 10-III-2018, fl., fr., F. S. Souto; F. C. P. Costa 49 (JPB); idem, Sítio Frade, 03-IV2018, fl., F. C. P. Costa 357.

Distribuição geográfica: Ocorrência exclusiva no Brasil nas regiões Nordeste (Bahia, Ceará, Paraíba, Pernambuco, Rio Grande do Norte) e Centro-Oeste (Goiás) (Flora do Brasil 2020 em construção).

Considerações: Chamaecrista amiciella é endêmica da Caatinga, ocorrendo principalmente em solos arenosos e altitudes entre 150 e 500 m (Queiroz 2009; Correia \& Conceição 2017). Facilmente distinguível das demais espécies estudadas, por apresentar tricomas glandulares nos ramos e nos frutos, além da corola assimétrica com manchas vermelhas na base das pétalas. 
Encontrada em mata aberta na base da serra, próxima a afloramentos rochoso. Coletada florida e frutificando nos meses de março e abril, correspondendo ao período chuvoso da região.

2. Chamaecrista duckeana (P. Bezerra \& Afr. Fern.) H.S. Irwin \& Barneby, Memoirs of the New York Botanical Garden 35: 861. 1982.

\section{Figura 4F-J}

Caracterização: Subarbusto ereto, ca. $35 \mathrm{~cm}$ alt.; ramos cilíndricos, indumento híspido. Estípulas $7 \mathrm{~mm}$ compr., lanceoladas, hispida. Folha 4-9 cm compr., 24-50-folioloada, folíolos 6-8 $83 \mathrm{~mm}$, oblongos, ápice mucronado, base assimétrica, margem inteira, face abaxial híspida e adaxial glabra; pecíolo $5 \mathrm{~mm}$ compr., híspido, pulvino extremamente reduzido, nectários extraflorais estipitados, peciolar. Racemos axilares reduzidos, 3-3.5 cm compr.; pedúnculo $3 \mathrm{~mm}$ compr., híspido. Flores 2.7-3 cm compr.; botões florais ovados, ápice acuminado; brácteas $3 \mathrm{~mm}$ compr., triangulares, persistentes, glabrescentes; bractéolas $2.4 \mathrm{~mm}$, triangulares, glabrescentes; pedicelo $15 \mathrm{~mm}$ compr., híspido; cálice com sépalas medindo $9 \times 4 \mathrm{~mm}$, ovadas, glabra na face adaxial e híspida na abaxial; corola zigomorfa, com uma das pétalas cuculada e com manchas vermelhas no ápice, pétalas 7-12 × 10-11 mm; estames $10,5 \mathrm{~mm}$ compr., anteras $4 \mathrm{~mm}$ compr., lineares; ovário $7 \mathrm{~mm}$ compr., híspido; estilete $6 \mathrm{~mm}$, glabro; estigma puntiforme. Legumes castanho claro, $3.5 \mathrm{~cm}$ compr., linear, híspido. Sementes não visualizadas.

Material examinado: BRASIL. Paraíba: Cajazeiras, Parque Ecológico Engenheiro Ávidos, Sítio Frade, 03-IV-2018, fl., F. C. P. Costa 349 (JPB); idem, 17-V-1992, fr., A. C. A. Moura; H. M. Moreira 17 (JPB).

Distribuição geográfica: Ocorrência no Brasil, exclusivamente na região Nordeste (Alagoas, Bahia, Ceará, Paraíba, Pernambuco, Piauí, Rio Grande do Norte, Sergipe) (Flora do Brasil 2020 em construção).

Considerações: Chamaecrista duckeana é endêmica da Caatinga, podendo representar uma forma robusta de C. calyciodes (Queiroz 2009). Facilmente reconhecida por apresentar corola zigomorfa com uma pétala cuculada apresentando manchas vermelhas no ápice. Coletada no PECEA em áreas abertas, florescendo no mês de abril, período de chuvas mais intensas na região.

3. Chamaecrista pilosa (L.) Greene, Memoirs of the New York Botanical Garden. 25(2): 720. 1982.

Figura 5A-E

Caracterização: Erva ereta, ca. $45 \mathrm{~cm}$ alt.; ramos eretos, indumento híspido. Estípulas $5 \mathrm{~mm}$ compr., lanceoladas, híspidas. Folha 3.3-3.7 cm compr., 16-18-folioladas, folíolos $11 \times 4-5 \mathrm{~mm}$, oblongos, ápice arredondado, base assimétrica, margem inteira com tricomas, glabros em ambas as faces, pecíolo $4 \mathrm{~mm}$ compr., híspido; pulvino $1 \mathrm{~mm}$ compr.; nectários extraflorais estipitados, peciolar. Flores isoladas, axilares, $12 \mathrm{~mm}$ compr.; brácteas ausentes; bractéolas $2 \mathrm{~mm}$ compr., aciculares, glabrescentes; botões florais ovados, ápice agudo-acuminado; pedicelo $9 \mathrm{~mm}$ compr., glabro; cálice com sépalas medindo $4 \times 1 \mathrm{~mm}$, lanceoladas, glabra na face adaxial e híspido na abaxial; corola zigomorfa, pétalas $3 \times 2 \mathrm{~mm}$; estames 5 , $3 \mathrm{~mm}$ compr., anteras $2 \mathrm{~mm}$ compr., cilíndricas; ovário $4 \mathrm{~mm}$ compr., velutino; estilete curvo, $3 \mathrm{~mm}$ compr., glabro; estigma capitado. Legume marrom, $20 \mathrm{~mm}$ compr., lineares, pubérulo. Sementes marrom-esbranquiçada, $2 \mathrm{~mm}$ compr.

Material examinado: BRASIL. Paraíba: Cajazeiras, Parque Ecológico Engenheiro Ávidos, Distrito Engenheiro Ávidos, 25-III-2017, fl., fr., F. S. Souto; A. A. Quaresma; M. S. Pereira 13 (JPB); idem, 13-IV-2018, fl., F. S. Souto; F. C. P. Costa 53 (JPB). 


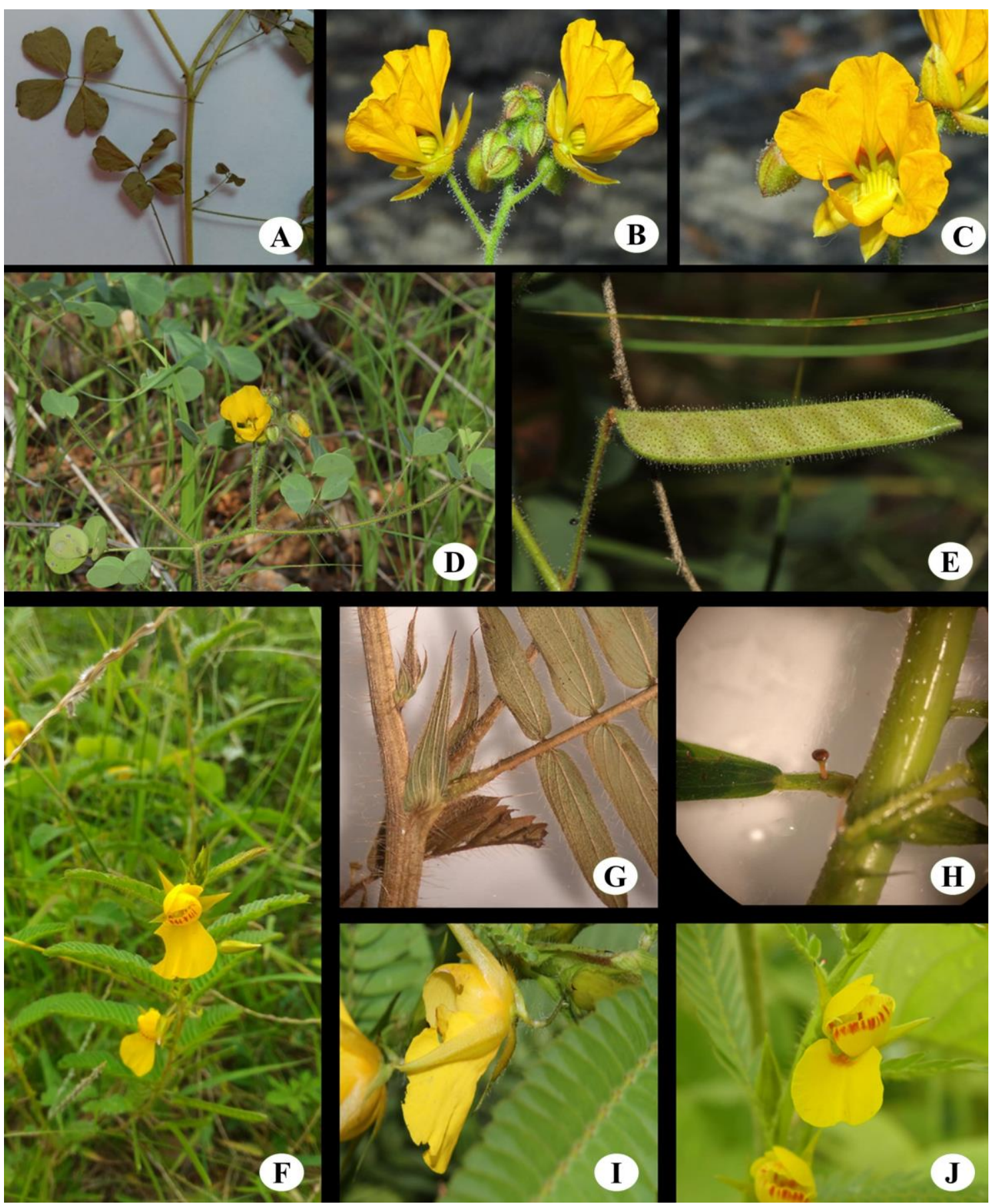

Figura 4A-E. Chamaecrista. amiciella: A. Folha, B. Inflorescência, C-D. Flor, E. Fruto; F-J. C. duckeana: F. Hábito, G. Estípula, H. Nectário extrafloral, I. Detalhe do cálice, J. Flor.

Distribuição geográfica: Ocorrência exclusiva no Brasil nas regiões Norte (Tocantins); Nordeste (Bahia, Ceará, Maranhão, Pernambuco, Rio Grande do Norte); Centro-Oeste (Goiás) e Sudeste (Minas Gerais) (Flora do Brasil 2020 em construção).

Considerações: Chamaecrista pilosa é uma espécie endêmica da Caatinga, ocorrendo em ambientes úmidos e solos arenosos, pedregosos e rasos, onde formam pequenas populações (Córdula 2008; Queiroz \& Loiola 2009). Distingue-se das demais encontradas na área pela combinação dos caracteres: erva ereta, com bractéolas aciculares e flores pequenas com cinco estames. Coletada em locais úmidos ou margem de estrada, durante o período chuvoso. Floresce e frutifica nos meses de março e abril. Chamaecrista pilosa está sendo aqui citada pela primeira 
vez como ocorrência no estado da Paraíba, tal informação está pautada a partir de consultas feitas nos materiais depositados nos Herbários visitados, na bibliografia especializada e base de dados disponíveis online, a exemplo da Flora do Brasil.

\section{Chamaecrista rotundifolia (Pers.) Greene, Pittonia 4: 31.1989.}

\section{Figura 5F-J}

Caracterização: Erva anual, ca. $25 \mathrm{~cm}$ compr.; ramos eretos, indumento híspido. Estípulas $10 \mathrm{~mm}$ compr., ovais, híspidas. Folha 2.7-3 cm compr., bifoliolada, folíolos $2.2-2.5 \times 1.5 \mathrm{~cm}$, obovais, ápice obtuso, base assimétrica, margem inteira, glabros em ambas as faces; pecíolo 4-5 $\mathrm{mm}$ compr., híspido, pulvino ausentes, nectários extraflorais ausentes. Flores isoladas, axilares, $7 \mathrm{~mm}$; brácteas ausentes; bractéolas $0.5 \mathrm{~mm}$ compr., lanceolada, glabras; botões florais ovados, ápice agudo; pedicelo 15-17 mm compr., glabro; cálice com sépalas medindo 6-7 $\times 2 \mathrm{~mm}$, lineareslanceoladas, glabra na face adaxial e híspido na abaxial; corola assimétrica, pétalas 6-7 $\times 3-6$ $\mathrm{mm}$; estames 5, 4-5 mm compr., anteras $2-3 \mathrm{~mm}$ compr., cilíndricas; ovário $5 \mathrm{~mm}$ compr., híspido; estilete $3 \mathrm{~mm}$ compr., glabro; estigma capitado. Legumes imaturos verdes, $2.9-3.8 \mathrm{~cm}$ compr., lineares, pubescentes. Sementes imaturas.

Material examinado: BRASIL. Paraíba: Cajazeiras, Parque Ecológico Engenheiro Ávidos, Distrito Engenheiro Ávidos, 25-III-2017, fl., fr., F. S. Souto; A. A. Quaresma; M. S. Pereira 14; idem, 13-IV2018, fl., F. S. Souto; F. C. P. Costa 54 (JPB).

Distribuição geográfica: América Central e do Sul (Queiroz 2009). No Brasil ocorre nas regiões Norte (Rondônia, Tocantins); Nordeste (Bahia, Ceará, Maranhão, Paraíba, Pernambuco, Piauí, Rio Grande do Norte); Centro-Oeste (Distrito Federal, Goiás, Mato Grosso do Sul, Mato Grosso); Sudeste (Espírito Santo, Minas Gerais, Rio de Janeiro, São Paulo) e Sul (Paraná, Rio Grande do Sul) (Flora do Brasil 2020 em construção).

Considerações: Chamaecrista rotundifolia é uma espécie invasora com ocorrência em áreas abertas, antropizadas, servindo de pastagem para o gado (Irwin \& Barneby 1982; Camargo \& Mioto 2004; Queiroz 2009; Souza \& Silva 2015). A combinação de caracteres, tais como: folhas bifolioladas, ausência de nectários extraflorais e flores isoladas com cinco estames de filetes curtos a diferencia das demais espécies coletadas na área de estudo. Encontrada no entorno da barragem ou ruderal, como também em ambientes de pastagem na base da serra. Apresentou-se florida nos meses de março, abril e agosto, mostrando-se resistente a escassez hídrica durante o período seco.

5. Chamaecrista serpens (L.) Greene, Pittonia 4: 29. 1899.

Figura 6A-D

Caracterização: Erva prostrada, ca. $20 \mathrm{~cm}$ compr.; ramos cilíndricos, indumento híspido. Estípulas $3 \mathrm{~mm}$ compr., triangulares, glabras. Folha 2.1-2.8 cm compr., 10-12-folioloada, folíolos 9-10 $\mathrm{mm} \times 3 \mathrm{~mm}$, oblanceolados, ápice mucronado, base assimétrica, margem inteira, ciliada, glabros em ambas as faces; pecíolo $2-3 \mathrm{~mm}$ compr., híspido; pulvino ausente; nectários extraflorais estipitados, peciolar. Flores isoladas, axilares, $15 \mathrm{~mm}$ compr.; botões florais ovados, ápice acuminado; brácteas ausentes; bractéolas $2 \mathrm{~mm}$ compr., triangulares, glabras; pedicelo 8 $10 \mathrm{~mm}$ compr., glabro; cálice com sépalas medindo 5-6 × 1.5-3 mm, deltoides- elíticas, glabras em ambas as faces; corola zigomorfa, pétalas 5-7 $\times 3-5 \mathrm{~mm}$; estames 10 , 3.5-4 mm compr., anteras 2.5-3 mm compr., lineares; ovário $3 \mathrm{~mm}$ compr., tomentoso; estilete curvo, $3 \mathrm{~mm}$ compr., glabro; estigma capitado. Legumes imaturos verdes, $2.2 \mathrm{~cm}$ compr., oblongo-lineares, tomentoso. Sementes imaturas. 


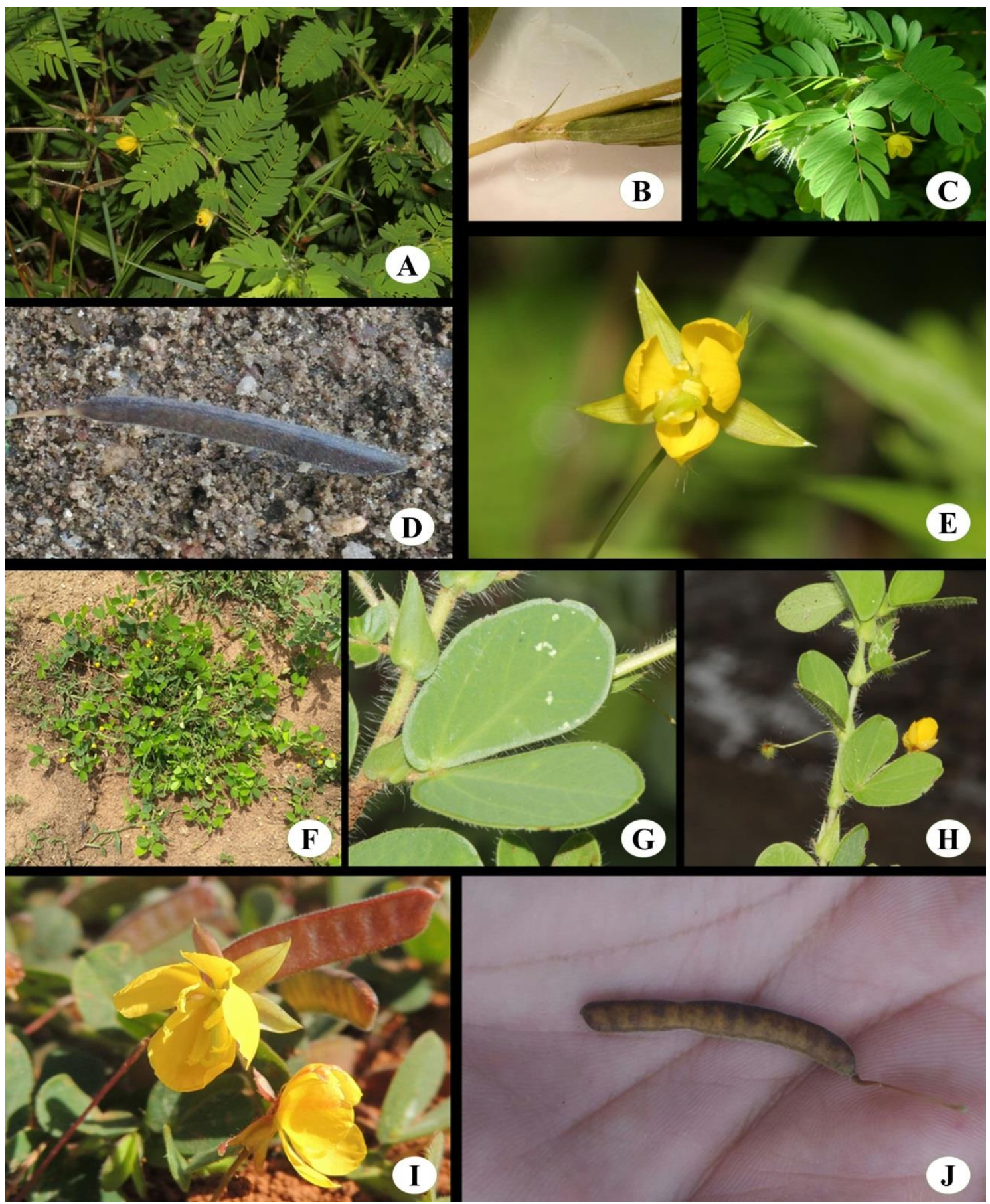

Figura 5A-E. Chamaecrista pilosa: A. Hábito, B. Estípula, G. Folha, D. Fruto, E. Flor; F-J. C. rotundifolia: F. Hábito, G-H. Folha e estípulas, I. Flor, J. Fruto.

Material examinado: BRASIL. Paraíba: Cajazeiras, Parque Ecológico Engenheiro Ávidos, Distrito Engenheiro Ávidos, 11-II-2017, fl., fr., F. S. Souto; A. A. Quaresma; W. P. Araújo; M. S. Pereira 01 (JPB).

Distribuição geográfica: América Central e do Sul (Queiroz \& Loiola 2009). No Brasil ocorre nas regiões Norte (Pará, Roraima, Tocantins); Nordeste (Alagoas, Bahia, Ceará, Maranhão, Paraíba, Pernambuco, Piauí, Rio Grande do Norte, Sergipe); Centro-Oeste (Mato Grosso do Sul, Mato Grosso) e Sudeste (Minas Gerais, São Paulo) (Flora do Brasil 2020 em construção). 
Considerações: Chamaecrista serpens é uma espécie invasora associada a solos arenosos em áreas degradadas, úmidas, sazonalmente inundadas (Irwin \& Barneby 1982; Queiroz 2009; Queiroz \& Loiola 2009). Facilmente reconhecida pelo seu hábito herbáceo prostrado, flores isoladas, pequenas e frutos oblongo-lineares, tomentosos. Encontrada em ambientes alagados ou margem de estrada, florescendo e frutificando durante o mês de fevereiro.

6. Chamaecrista supplex (Mart. ex Benth.) Britton \& Rose ex Britton \& Killip, Ann. New York Acad. Sci. 35: 185. 1936.

\section{Figura 6E-I}

Caracterização: Erva prostrada, ca. $35 \mathrm{~cm}$ compr; ramos cilíndricos, indumento hirsuto. Estípulas $3 \mathrm{~mm}$ compr., cordiformes, hirsutas. Folha 1.1-2.1 cm compr., 8-12-folioloada, folíolos 3-6 $\times 2-3$ $\mathrm{mm}$, oblongos, ápice agudo, base assimétrica, margem inteira, ciliada, face abaxial hirsuta e adaxial glabra; pecíolo 3-4 $\mathrm{mm}$ compr., hirsuto; pulvino ausente; nectários extraflorais estipitados, peciolar. Flores isoladas, axilares, $8 \mathrm{~mm}$ compr.; botões florais ovados, ápice acuminado; brácteas ausentes; bractéolas 1-2 mm compr., lanceoladas, glabras; pedicelo $4 \mathrm{~mm}$ compr., hirsuto; cálice com sépalas medindo $3 \times 1 \mathrm{~mm}$, lanceoladas, glabra na face adaxial e hirsuta na abaxial; corola zigomorfa, pétalas $3 \times 2-4 \mathrm{~mm}$; estames $5.2 \mathrm{~mm}$ compr., anteras 1 mm compr., oblongas; ovário $2 \mathrm{~mm}$ compr., hirsuto; estilete $2 \mathrm{~mm}$ compr., glabro; estigma capitado. Legumes imaturos verdes, $11 \mathrm{~mm}$ compr., lineares, hirsutos. Sementes imaturas.

Material examinado: BRASIL. Paraíba: Cajazeiras, Parque Ecológico Engenheiro Ávidos, Distrito Engenheiro Ávidos, fl., fr., 27-III-2017, F. S. Souto; A. A. Quaresma; M. S. Pereira 17(JPB).

Distribuição geográfica: Ocorrência exclusiva no Brasil nas regiões Norte (Pará, Tocantins); Nordeste (Bahia, Ceará, Maranhão, Paraíba, Pernambuco, Piauí, Rio Grande do Norte); CentroOeste (Distrito Federal, Goiás, Mato Grosso) e Sudeste (Minas Gerais, Rio de Janeiro) (Flora do Brasil 2020 em construção).

Considerações: Chamaecrista supplex é de origem nativa com ampla distribuição na Caatinga em áreas abertas que são sazonalmente inundadas, apresentando ciclo de vida rápido (Irwin \& Barneby 1982; Queiroz 2009; Flora do Brasil 2020 em construção). Reconhecida pela combinação dos seguintes caracteres: erva prostrada, estípula cordiforme, frutos lineares com $11 \mathrm{~mm}$ compr., hirsutos. Distribui-se na área de estudo nas margens das trilhas, onde é sazonalmente inundada. Floresce e frutifica no mês de março.

Senna Mill., Gard. Dict. Abr. ed. 4, v. 3. 1754.

Caracterização: Árvores, arbustos, subarbustos ou ervas; ramos jovens verdes exceto em Senna occidentalis (verdes-vináceos), cilíndricos, inermes. Estípulas verdes, laterais, basifixas, persistentes com exceção de $S$. alata. Folhas alternas, compostas, paripinadas, 3-17 pares de folíolos, membranáceos; nectários extraflorais ausentes ou presentes. Inflorescências em racemos axilares ou panículas terminais; botões florais obovados; brácteas caducas ou persistentes; bractéolas ausentes. Flores andróginas, monoclinas, hipóginas, diclamídeas, pediceladas; cálice dialissépalo, pentâmero, sépalas verdes, amarelas ou verde-amarelada; corola dialipétala, pentâmera, zigomorfa (exceto em S. spectabilis), pétalas amarelas, unguiculadas, obovadas, glabras em ambas as faces; estames 10, dialistêmone, heterodínamos, sendo que os 3 abaxiais são estaminoidais; filetes glabros; anteras amarelas, basifixas, deiscência apical, poricida, glabras; ovário súpero, unicarpelar, unilocular, placentação marginal; estilete cilíndrico, arqueado; estigma capitado ou globoso, glabro. Legumes cilíndricos, lineares, linearesquadrangulares oblongo-lineares, glabro ou piloso. Sementes quadrangulares ou oblongas, glabras. 
Considerações: O gênero Senna possui distribuição Pantropical, com cerca 300 espécies, das quais 80 ocorrem no Brasil e 27 são endêmicas (Irwin \& Barneby 1982; Queiroz 2009; Flora do Brasil 2020 em construção). Suas espécies são importantes na composição de paisagens particulares da Caatinga, sendo facilmente reconhecidas por apresentarem flores relativamente grandes com pétalas e anteras amarelas, deiscentes por poros apicais (Queiroz 2009).

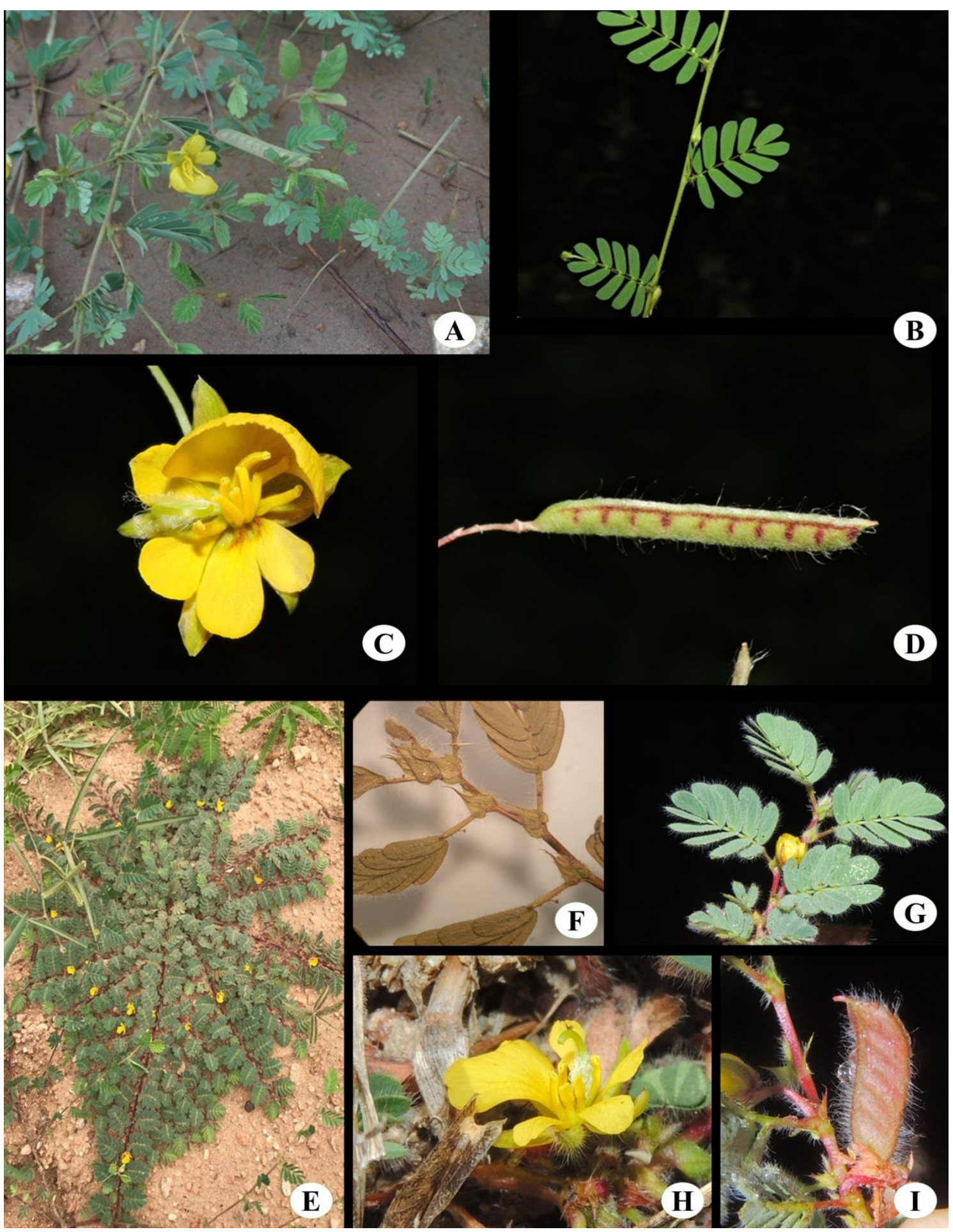

Figura 6A-D. Chamaecrista serpens: A. Hábito, B. Folha, C. Flor, D. Fruto; E-I. C. supplex: E. Hábito, F. Estípula, G. Folha, H. Flor, I. Fruto. 
7. Senna alata (L.) Roxb., Flora indica 2: 349. 1824.

Figura 7A-G

Caracterização: Arbustos, ca. 1-1.5 m alt.; ramos verdes, glabrescentes. Estípulas 5 mm compr., triangulares, glabras. Folha 25-34 cm compr., 14-8-folioloada, folíolos 4.3-14 × 4-8.3 cm, oblongos, ápice arredondado, base obliqua, margem inteira, glabros em ambas as faces; pecíolo $5 \mathrm{~cm}$ compr., glabro a curtamente pubérulos; pulvino $11 \mathrm{~mm}$ compr.; nectários extraflorais ausentes. Racemos terminais, 34-42 cm compr., carnosos, com um grande número de botões agrupadas no ápice da inflorescência; pedúnculo 12-14 cm compr., pubescente. Flores 2.5-2.8 cm compr.; brácteas petaloides, 18-22 × 9-11 mm compr., obovadas, caducas, glabras; pedicelo 5 mm compr., pubescentes; cálice com sépalas amarelas, 17 x $9 \mathrm{~mm}$, ovadas, glabra em ambas as faces; corola assimétrica, pétalas 17-22 × 8-11 $\mathrm{mm}$; estames com filetes curtos, anteras oblongas, sendo 2 estames laterais com filetes $3.2-4.7 \mathrm{~mm}$ e anteras $10 \mathrm{~mm}$, 1 estame centroabaxial com filete $8 \mathrm{~mm}$ e antera $4 \mathrm{~mm}, 4$ estames medianos com filetes $2.8 \mathrm{~mm}$ e anteras $3 \mathrm{~mm}$ e 3 estames abaxiais filetes com $2 \mathrm{~mm}$ e anteras $1 \mathrm{~mm}$; ovário $14 \mathrm{~mm}$ compr., pubescente; estilete $5 \mathrm{~mm}$, glabro; estigma capitado. Legume enegrecido, $12-15 \mathrm{~cm}$ compr., lineares com valvas aladas, glabros. Sementes imaturas.

Material examinado: BRASIL. Paraíba: Cajazeiras, Parque Ecológico Engenheiro Ávidos, Distrito Engenheiro Ávidos, 26-V-2017, fl., F. S. Souto; M. L. Teles 25 (JPB); idem, 26-VI-2017, fl., fr., F. S. Souto; M. L. Teles 30 (JPB).

Distribuição geográfica: América do Norte, Central e do Sul (Irwin \& Barneby 1982). No Brasil ocorre nas regiões Norte (Acre, Amazonas, Amapá, Pará, Rondônia, Tocantins); Nordeste (Alagoas, Bahia, Ceará, Maranhão, Paraíba, Pernambuco, Piauí, Rio Grande do Norte); CentroOeste (Distrito Federal, Goiás, Mato Grosso do Sul, Mato Grosso); Sudeste (Espírito Santo, Minas Gerais, Rio de Janeiro, São Paulo) e Sul (Paraná, Rio Grande do Sul, Santa Catarina) (Flora do Brasil 2020 em construção).

Considerações: Senna alata é uma espécie invasora amplamente cultivada em algumas regiões do mundo para fins medicinais e ornamentação urbana, na Caatinga é comumente encontrada em locais úmidos e que sofrem interferências antrópicas (Irwin \& Barneby 1982; Córdula 2008; Queiroz 2009). Facilmente reconhecida por apresentar inflorescências carnosas, brácteas petaloides e frutos com valvas aladas. Coletada em ambientes úmidos no entorno da barragem, possuindo associação com formigas e sendo comumente visitada por abelhas. Floresce e frutifica nos meses de maio e junho, coincidindo com o fim do período chuvoso e início de estiagem.

8. Senna obtusifolia (L.) H.S. Irwin \& Barneby, Memoirs of the New York Botanical Garden 35: 252. 1982.

\section{Figura 7D-F}

Caracterização: Arbustos, ca. $1 \mathrm{~m}$ alt.; ramos verdes, glabros. Estípulas $8 \mathrm{~mm}$ compr., lineares a lanceoladas, glabrescentes. Folha 6-11.5 cm compr., 6-folioloada, folíolos 3.7-6.7 cm × 1.8-3.5 $\mathrm{cm}$, obovados, ápice mucronado a retuso, base obliqua, margem inteira, glabros na face adaxial e pubescente na face abaxial; pecíolo $3.5-4.1 \mathrm{~cm}$ compr., pubescentes; pulvino $7 \mathrm{~mm}$ compr; nectários cilíndricos localizados na raque foliar, exclusivamente entre o primeiro par de folíolos. Racemos axilares, 4-4.8 cm compr.; pedúnculo $3 \mathrm{~mm}$ compr. Flor 3-3.4 cm compr.; brácteas 4-9 mm compr., lineares, persistentes, pubescentes; pedicelo 1.5-2 cm compr., glabro; cálice com sépalas verdes, 9-10 × 4-6 mm, obovadas, glabrescentes a pubescentes em ambas as faces; corola zigomorfa, pétalas 7-13 × 6-7 mm; estames com filetes curtos, anteras lineares a oblongas, sendo estames laterais com filetes $3 \mathrm{~mm}$ e anteras $4 \mathrm{~mm}$, 1 estame centro-abaxial com filete 2-3 mm e antera $4 \mathrm{~mm}, 4$ estames medianos com filetes $2 \mathrm{~mm}$ e anteras $3 \mathrm{~mm}$ e 3 estames abaxiais com 1-2 mm de comprimento; ovário $10 \mathrm{~mm}$ compr., pubescente; estilete $3 \mathrm{~mm}$ compr., 
glabrescente; estigma globoso. Legume castanho escuro, 14-16 cm compr., cilíndricos, curvos, glabrescentes. Sementes marrons, 4-5 mm compr., irregulares.

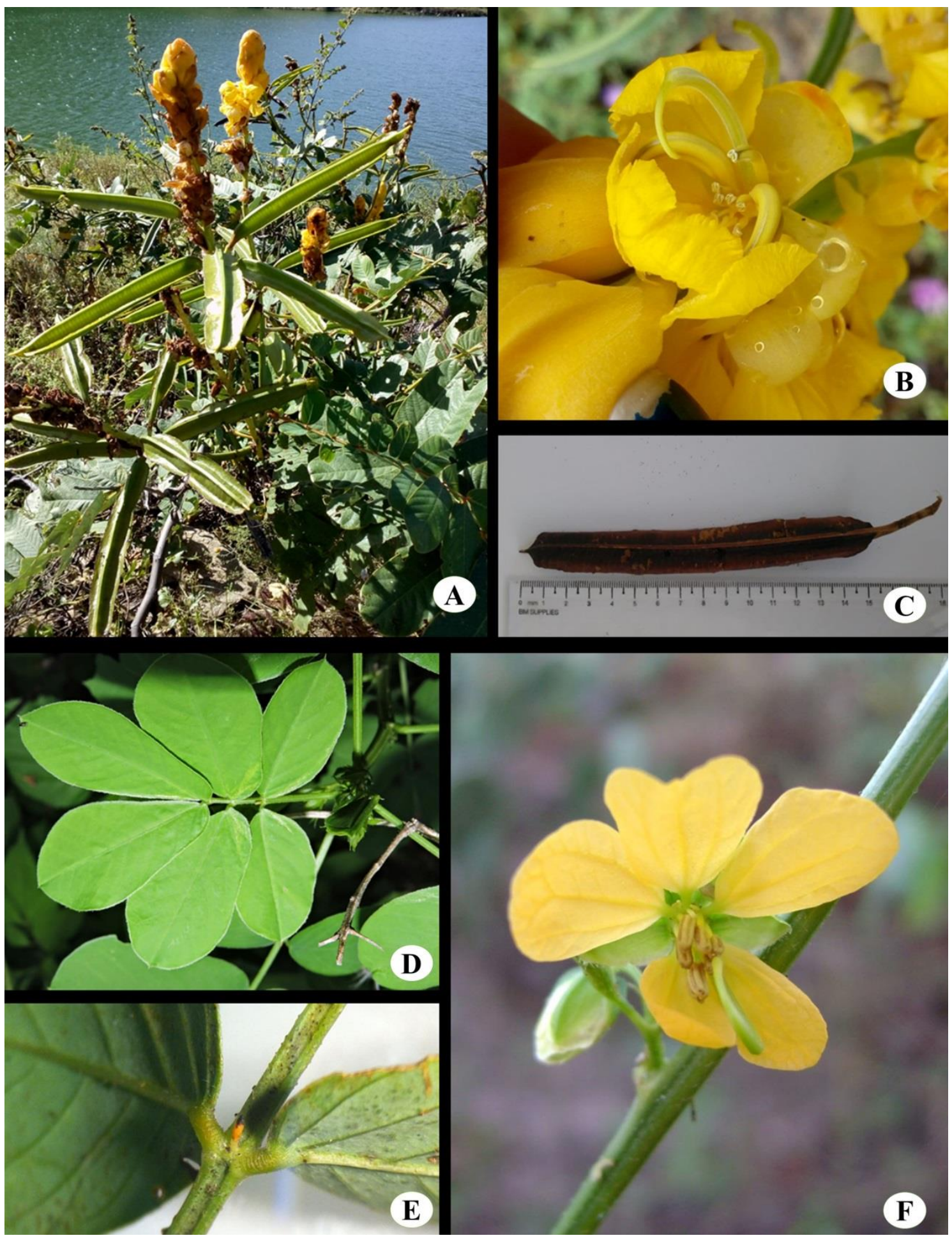

Figura 7A-C. Senna alata: A. Hábito, B. Flor, C. Fruto; D-F. S. obtusifolia: D. Folha, E. Nectário extrafloral, F. Flor.

Material examinado: BRASIL. Paraíba: Cajazeiras, Parque Ecológico Engenheiro Ávidos, Distrito Engenheiro Ávidos, 11-III-2017, fl., F. S. Souto; A. A. Quaresma; M. S. Pereira 09 (JPB); idem, 08IV-2017, fl., fr., F. S. Souto; A. A. Quaresma; M. S. Pereira 23; idem, 16-VIII-2017, fl., F. S. Souto; M. L. Teles $32(\mathrm{JPB})$. 
Distribuição geográfica: Continentes Americano, Asiático e Africano (Irwin \& Barneby 1982). No Brasil ocorre nas regiões Norte (Acre, Amazonas, Pará, Rondônia, Roraima, Tocantins); Nordeste (Alagoas, Bahia, Ceará, Maranhão, Paraíba, Pernambuco, Piauí, Rio Grande do Norte); CentroOeste (Distrito Federal, Goiás, Mato Grosso do Sul, Mato Grosso); Sudeste (Minas Gerais, Rio de Janeiro, São Paulo) e Sul (Paraná) (Flora do Brasil 2020 em construção).

Considerações: Senna obtusifolia é uma espécie invasora encontrada na Caatinga fértil durante todo o ano em ambientes degradados, pastagens e áreas agricultáveis (Irwin \& Barneby 1982; Queiroz 2009; Santos et al. 2017). Este táxon é facilmente reconhecido por apresentar frutos curvados, ramos glabros e nectário extrafloral exclusivamente entre o primeiro par de folíolos. Foi coletada na área de estudo em áreas abertas que sofrem interferência antrópica. Coletada com flor e fruto nos meses de março, abril e agosto. Conhecida popularmente como "mata pasto".

9. Senna occidentalis (L.) Link, Handbuch zur Erkennung der nutzbarsten und am häufigsten vorkommenden Gewächse 2: 140. 1829.

\section{Figura 8A-G}

Caracterização: Arbusto ereto, ca. 1-1.2 m alt.; ramos verdes-vináceos, glabrescentes. Estípulas 6 $\mathrm{mm}$ compr., triangulares, glabras. Folha 17-21 cm compr., 8-10-folioloada, folíolos 3.5-8.6 cm $\times$ 2.7-6 cm, elípticos, ápice agudo a acuminado, base obliqua, margem inteira, glabros em ambas as faces; pecíolo $3.5 \mathrm{~cm}$ compr., glabro; pulvino ausente; nectários extraflorais localizados no pecíolo, ovoides, sésseis. Racemos axilares, 3-3.2 cm compr.; pedúnculo $6 \mathrm{~mm}$ compr., glabro. Flor $2 \mathrm{~cm}$ compr.; brácteas 7-12 mm compr., lanceoladas, caducas, glabras; pedicelo $7 \mathrm{~mm}$ compr., glabro; cálice com sépalas verdes, $10 \times 6 \mathrm{~mm}$, obovais a elípticas, glabra em ambas as faces; corola zigomorfa, pétalas 12-13 $\times 7-8 \mathrm{~mm}$; estames com filetes curtos, anteras oblongas, sendo 2 estames laterais com filetes $6 \mathrm{~mm}$ e anteras $5 \mathrm{~mm}$, 1 estame centro-abaxial com filete 4 $\mathrm{mm}$ e antera $3 \mathrm{~mm}, 4$ estames medianos com filetes $3 \mathrm{~mm}$ e anteras $3-4 \mathrm{~mm}$ e 3 estames abaxiais filetes com $2 \mathrm{~mm}$; ovário $9 \mathrm{~mm}$ compr., pubescente; estilete $3 \mathrm{~mm}$ compr., glabrescente; estigma capitado. Legumes castanho escuros, 10.5-11.7 cm compr., lineares-quadrangulares, glabrescentes. Sementes marrons, $4 \mathrm{~mm}$ compr., oblongas.

Material examinado: BRASIL. Paraíba: Cajazeiras, Parque Ecológico Engenheiro Ávidos, Distrito Engenheiro Ávidos, 27-III-2017, f1., fr., F. S. Souto; M. S. Pereira 18 (JPB).

Distribuição geográfica: Continentes Americano, Asiático e Africano (Irwin \& Barneby 1982). No Brasil ocorre nas regiões Norte (Acre, Amazonas, Amapá, Pará, Rondônia, Roraima, Tocantins); Nordeste (Alagoas, Bahia, Ceará, Maranhão, Paraíba, Pernambuco, Piauí, Rio Grande do Norte, Sergipe); Centro-Oeste (Distrito Federal, Goiás, Mato Grosso do Sul, Mato Grosso); Sudeste (Espírito Santo, Minas Gerais, Rio de Janeiro, São Paulo) e Sul (Paraná, Rio Grande do Sul, Santa Catarina) (Flora do Brasil 2020 em construção).

Considerações: Senna occidentalis é uma espécie invasora com distribuição Paleotropical, sendo possivelmente introduzida na América. Ocorre na Caatinga em áreas degradadas e ambientes ruderais (Irwin \& Barneby 1982; Queiroz 2009; Dantas \& Silva 2013; Souza \& Silva 2016). Facilmente reconhecida por apresentar folíolos elípticos, nectário extrafloral ovoide, séssil, peciolar e frutos lineares-quadrangulares. Encontrada em margem de estrada, florescendo e frutificando no mês de março na área de estudo. Conhecida na região como "manjioba”.

10. Senna siamea (Lam.) H.S. Irwin \& Barneby, Memoirs of the New York Botanical Garden 35: 98. 1982.

Figura 8D-G 
Caracterização: Árvores, ca. 3.5-4 m alt.; ramos verdes, glabros e pouco ramificados. Estípulas $1 \mathrm{~mm}$ compr., triangulares, glabras. Folha 10-13 cm compr., 8-22-folioloada, folíolos 2.5-5.5 $\times$ $1.5-2 \mathrm{~cm}$, oblongos, ápice obtuso, base cuneada, margem inteira, glabros em ambas as faces; pecíolo $2 \mathrm{~cm}$ compr., glabro; pulvino $3 \mathrm{~mm}$ compr.; nectários extraflorais ausentes. Panículas terminais, 8-17 cm compr.; pedúnculo $1.2-2.5 \mathrm{~cm}$ compr., glabros. Flor 4-4.2 cm compr.; brácteas 3-4 mm compr., estreitamente triangulares, caducas, glabras; pedicelo $2.3-2.5 \mathrm{~cm}$ compr., glabro; cálice com sépalas verde/amareladas, 8-10 × 4-6 mm, ovada, glabra em ambas as faces; corola zigomorfa, pétalas 12-15 × 5-6 mm; estames com filetes longos, anteras curvas, sendo 2 estames laterais com filetes $10 \mathrm{~mm}$ e a anteras $5 \mathrm{~mm}, 1$ estame centro-abaxial com filetes $5 \mathrm{~mm}$ e antera $4 \mathrm{~mm}, 4$ estames medianos com filetes $4 \mathrm{~mm}$ e anteras $5 \mathrm{~mm}, 3$ estames abaxiais filetes com $3 \mathrm{~mm}$ e anteras $2 \mathrm{~mm}$; ovário $11 \mathrm{~mm}$ compr., pubescente; estilete $6 \mathrm{~mm}$ compr., glabro; estigma capitado. Legumes marrons, 21-28 cm compr., lineares, valvas corrugadas, glabros. Sementes castanhas, 4-5 mm compr., oblongas.

Material examinado: BRASIL. Paraíba: Cajazeiras, Parque Ecológico Engenheiro Ávidos, Distrito Engenheiro Ávidos, 25-III-2017, fl., fr., F. S. Souto; A. A. Quaresma; M. S. Pereira 15 (JPB).

Distribuição geográfica: Continentes Asiático e Americano (Irwin \& Barneby 1982). No Brasil ocorre nas regiões Norte (Amazonas, Pará, Rondônia); Nordeste (Alagoas, Bahia, Ceará, Maranhão, Paraíba, Pernambuco, Piauí); Centro-Oeste (Distrito Federal, Goiás); Sudeste (Minas Gerais, Rio de Janeiro, São Paulo) e Sul (Rio Grande do Sul, Santa Catarina) (Flora do Brasil 2020 em construção).

Considerações: Senna siamea é originária da Tailândia, sendo utilizada e cultivada para ornamentação de praças na região das Américas (Irwin \& Barneby 1982; Rodrigues et al. 2005). Reconhecida pelo hábito arbóreo, folhas com 4-11 pares de folíolos, estípulas triangulares, ausência de nectários extraflorais e corola zigomorfa. Encontrada em ambientes ruderais, com floração no mês de março. Conhecida na região como "canafístula".

11. Senna spectabilis (DC.) H.S. Irwin \& Barneby, Memoirs of the New York Botanical Garden 35: 600. 1982.

Figura 9A-E

Caracterização: Árvores, ca. 6-7 m alt.; ramos verdes, pubescentes. Estípulas $4 \mathrm{~mm}$ compr., lineares, pubescentes. Folha 20-23 cm compr., 26-34-folioloada, folíolos 2.3-3.5 × 1.4-1.7 cm, oblongos ou elípticos, ápice obtuso, base obliqua, margem inteira, glabros em ambas as faces; pecíolo 2.3-2.9 cm compr., pubescentes; pulvino $3 \mathrm{~mm}$ compr.; nectários extraflorais ausentes. Panículas terminais, $34-36 \mathrm{~cm}$ compr.; pedúnculo $8 \mathrm{~cm}$ compr., pubescentes. Flor $4.5-5 \mathrm{~cm}$ compr.; brácteas $4 \mathrm{~mm}$, lineares, caducas, glabras; cálice com sépalas verdes/amareladas, 6-7 ×5 $\mathrm{mm}$, oblongas, pubescentes em ambas as faces; corola assimétrica, pétalas $2.4 \times 1.6-1.9 \mathrm{~cm}$; estames com filetes curtos, anteras curvas, sendo 2 estames laterais com filetes $3 \mathrm{~mm}$ e anteras 6 $\mathrm{mm}, 1$ estame centro-abaxial com filete $2.1 \mathrm{~mm}$ e antera $5.4 \mathrm{~mm}, 4$ estames medianos com filetes $2.4 \mathrm{~mm}$ e anteras $5 \mathrm{~mm}$ e 3 estames abaxiais filetes com $2 \mathrm{~mm}$ e anteras $1 \mathrm{~mm}$; ovário 17 mm compr., glabro; estilete $7 \mathrm{~mm}$ compr., glabro; estigma capitado. Câmara marrom, 18-25 cm compr., cilíndrico, glabros. Sementes não observadas.

Material examinado: BRASIL. Paraíba: Cajazeiras, Parque Ecológico Engenheiro Ávidos, Distrito Engenheiro Ávidos, 19-II-2017, fl., F. S. Souto; A. A. Quaresma; M. S. Pereira 06 (JPB); idem, São João do Tigre, Área de Proteção Ambiental, Serra do Paulo, 13/III/2010, fr., P. C. Gadelha Neto; G. B. Sena Júnior, M. C. Pessoa; J. R. Lima; G. B. Freitas; R. A. Pontes; G. C. Delgado Júnior 2730 (JPB); BRASIL: Pernambuco: Fazenda “Os Campos”, 10/XI/1941, fr., L. P. Xavier s.n. (JPB). 


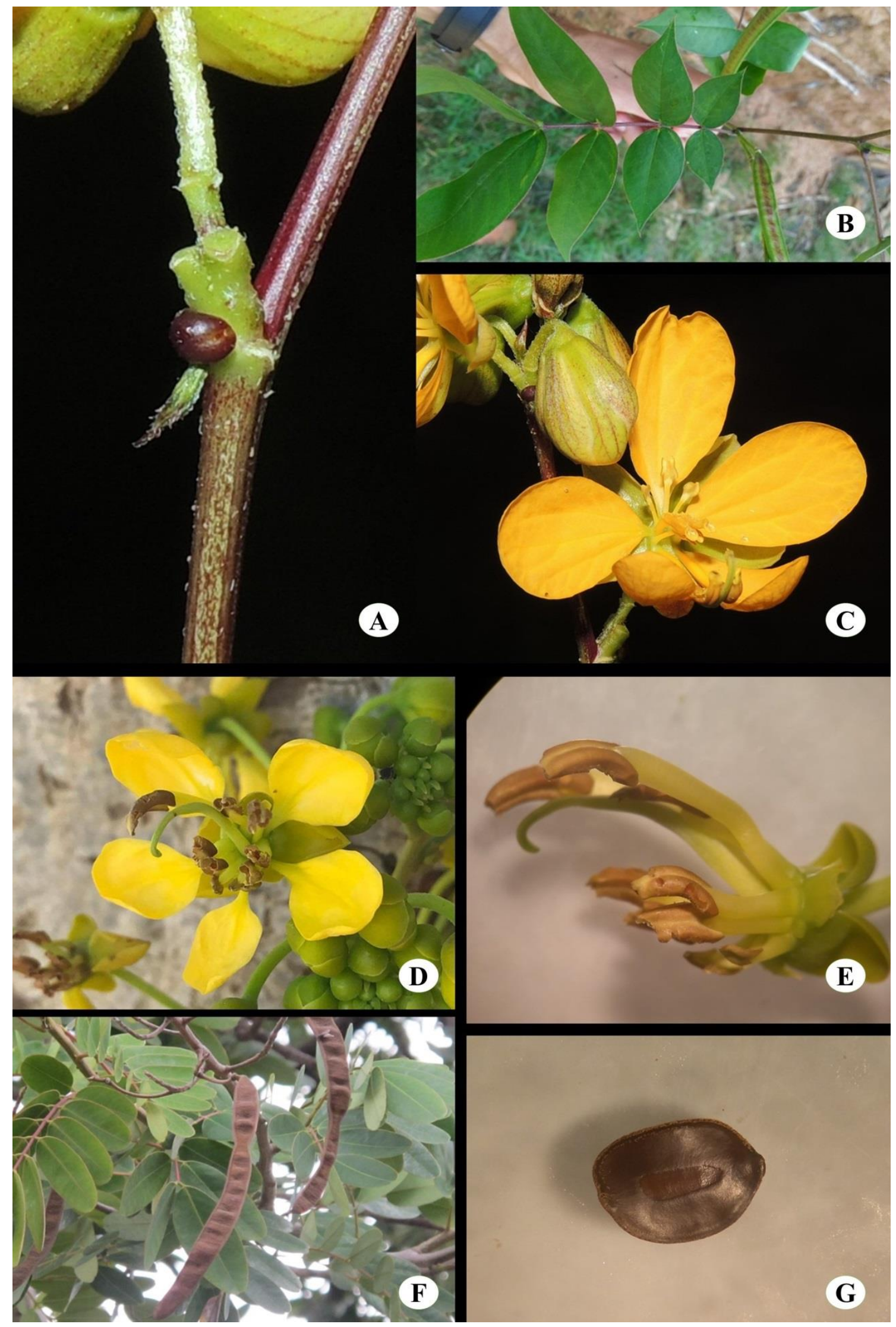

Figura 8A-G. Senna occidentalis: A. Nectário extrafloral, B. Folha, G. Flor; D-G. S. siamea: D. Flor, E. Androceu e gineceu, F. Fruto, G. Semente. 
Distribuição geográfica: Região Neotropical (Irwin \& Barneby 1982). No Brasil ocorre nas regiões Norte (Acre, Pará, Tocantins); Nordeste (Alagoas, Bahia, Ceará, Maranhão, Paraíba, Pernambuco, Piauí, Rio Grande do Norte, Sergipe); Centro-Oeste (Distrito Federal, Goiás, Mato Grosso do Sul, Mato Grosso) e Sudeste (Minas Gerais) (Flora do Brasil 2020 em construção).

Considerações: Senna spectabilis é cultivada e utilizada na ornamentação urbana. No Brasil distribui-se em bordas de florestas litorâneas, cerrado sensu lato e Caatinga (Irwin \& Barneby 1982; Rodrigues et al. 2005; Santos et al. 2017). Pode ser facilmente reconhecida por apresentar os seguintes caracteres: hábito arbóreo, folhas com 13-17 pares de folíolos e corola assimétrica. $\mathrm{Na}$ área de estudo foi encontrada próxima a estrada que dá acesso ao Parque, florida no mês de fevereiro.

12. Senna uniflora (Mill.) H.S. Irwin \& Barneby, Memoirs of the New York Botanical Garden 35: 258. 1982.

Figura 9F-G

Caracterização: Subarbusto, ca. $50 \mathrm{~cm}$ alt.; ramos verdes, velutinos. Estípulas $15 \mathrm{~mm}$ compr., lineares, velutinas. Folha 8-12.3 cm compr., 8-foliolada, folíolos 2.8-5.3 × 1.5-4.2 cm, obovados, ápice arredondado, base assimétrica, margem inteira, face adaxial glabra e abaxial velutina; pecíolo $2.5-2.8 \mathrm{~cm}$ compr., velutinos; pulvino $4 \mathrm{~mm}$ compr.; nectários fusiformes localizados na raque foliar, distribuídos entre todos os pares de folíolos. Racemos axilares, $2-2.3 \mathrm{~cm}$ compr.; pedúnculo 5-7 mm compr., velutino. Flor $1.7 \mathrm{~cm}$; brácteas $8 \mathrm{~mm}$, lineares, persistentes a caducas, velutinas; pedicelo $2 \mathrm{~mm}$ compr., velutino; cálice com sépalas verdes, $4 \mathrm{~mm} \times 2 \mathrm{~mm}$, obovadas-oblongas, face adaxial glabra e abaxial velutina; corola zigomorfa, pétalas $6 \times 3 \mathrm{~mm}$; estames com filetes curtos, anteras oblongas, sendo 2 estames laterais com filetes $2 \mathrm{~mm}$ e anteras $1 \mathrm{~mm}, 1$ estame centro-abaxial com filete $2 \mathrm{~mm}$ e antera $1 \mathrm{~mm}, 4$ estames medianos com filetes $1 \mathrm{~mm}$ e anteras $1 \mathrm{~mm}$ e 3 estames abaxiais com $1 \mathrm{~mm}$; ovário $7 \mathrm{~mm}$ compr., velutino; estilete $2 \mathrm{~mm}$ compr., velutino; estigma capitado. Legumes castanho-escuros, 4-5.1 cm compr., lineares-oblongos, velutinos. Sementes castanhas, $4 \mathrm{~mm}$ compr., quadrangulares.

Material examinado: BRASIL. Paraíba: Cajazeiras, Parque Ecológico Engenheiro Ávidos, 26-V2017, fl., F. S. Souto; M. L. Teles 29 (JPB); idem, 10-III-2018, fl., fr., F. S. Souto; F. C. P. Costa 47 (JPB).

Distribuição geográfica: América Central, México e América do Sul (Irwin \& Barneby 1982). No Brasil ocorre nas regiões Norte (Roraima); Nordeste (Alagoas, Bahia, Ceará, Maranhão, Paraíba, Pernambuco, Piauí, Rio Grande do Norte, Sergipe); Centro-Oeste (Goiás) e Sudeste (Minas Gerais, São Paulo) (Flora do Brasil 2020 em construção).

Considerações: Senna uniflora é uma espécie invasora com ocorrência em ambientes perturbados. Na Caatinga ocorre em ambientes úmidos e em pastagens abandonadas (Irwin \& Barneby 1982; Córdula 2008; Queiroz 2009; Santos et al. 2017). Diferencia-se por apresentar indumento velutino nos ramos, na face abaxial dos folíolos e ovário, frutos pequenos, linearesoblongos. Frequente no PECEA em áreas abertas e trilhas na base da serra, florescendo e frutificando de março a maio. 


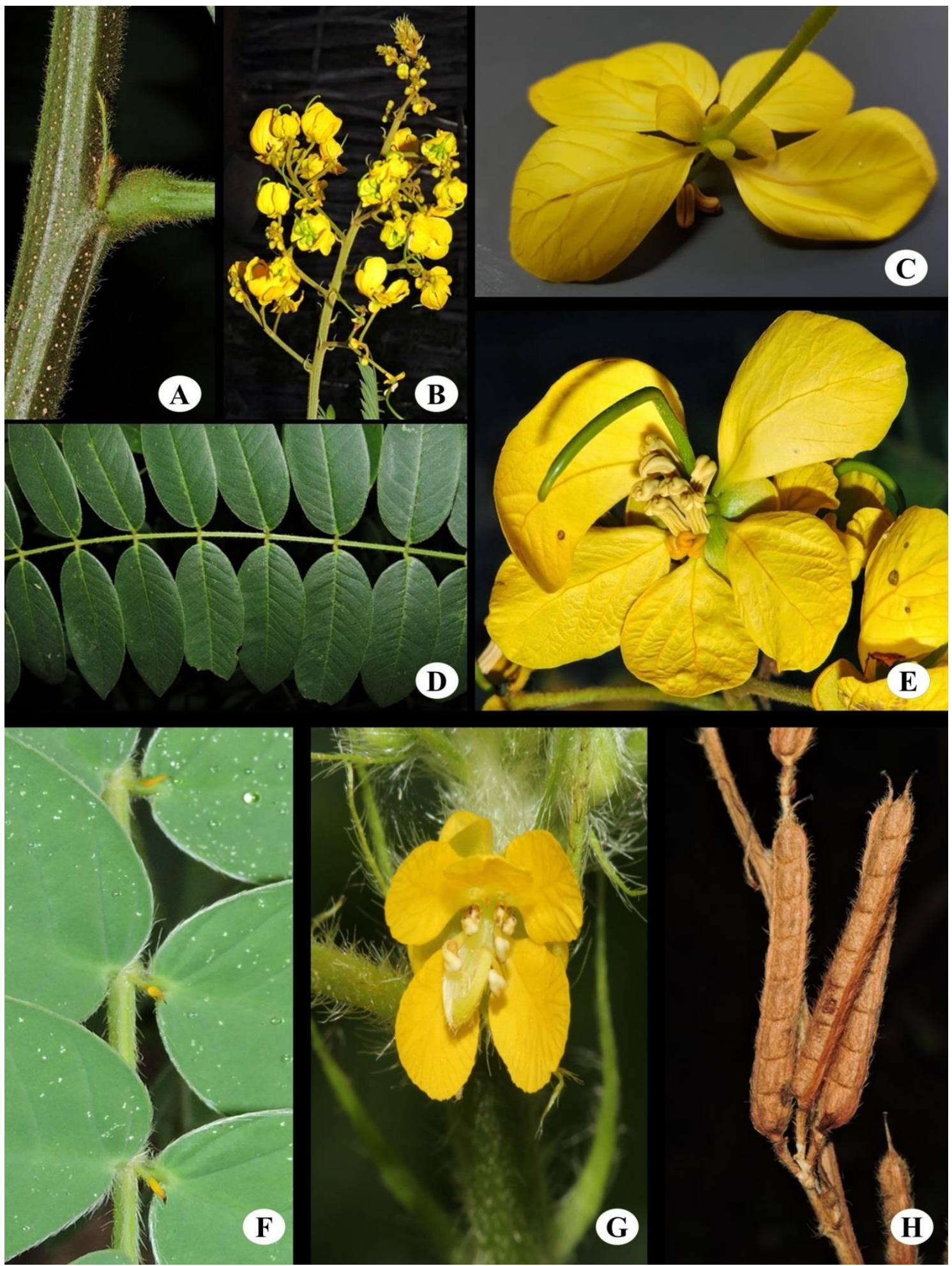

Figura 9A-E. Senna spectabilis: A. Estípula, B. Inflorescência, C. Cálice, D. Folha, E. Flor; F-H. S. uniflora: F. Nectário extrafloral, G. Flor, H. Fruto.

\section{Agradecimentos}

Aos avaliadores pela revisão crítica do manuscrito. À equipe técnica do Herbário Lauro Pires Xavier (JPB) e do Laboratório de Botânica do CFP/UFCG pelas contribuições neste trabalho. 


\section{Referências}

Amorim L.D.M., Souza L.O.F., Oliveira F.F.M., Camacho R.G.V. \& Melo J.I.M. (2016) Fabaceae na Floresta Nacional (FLONA) de Assú, semiárido potiguar, nordeste do Brasil. Rodriguésia, 67(1): 105-123.

Araújo G.M. (2009) Matas ciliares da caatinga: florística, processo de germinação e sua importância na restauração de áreas degradadas. Dissertação de Mestrado, Programa de PósGraduação em Botânica. Universidade Federal Rural de Pernambuco, Recife, Pernambuco.

Bandeira A.N.T. (2016) Convolvulaceae Juss. em uma unidade de conservação do semiárido Paraibano, Nordeste do Brasil. Dissertação de Mestrado, Programa de Pós-Graduação em Biodiversidade Vegetal. Universidade do Estado da Bahia, Paulo Afonso, Bahia.

Camargo R.A. \& Miotto S.T.S. (2004) O gênero Chamaecrista Moench (LeguminosaeCaesalpinioideae) no Rio Grande do Sul. Iheringia, 59(2): 131-148.

Cardoso D.B.O.S. \& Queiroz L.P. (2007) Diversidade de Leguminosae nas caatingas de Tucano, Bahia: implicações para a fitogeografia do semi-árido do Nordeste do Brasil. Rodriguésia, 58(2): 379-391.

Córdula E. (2008) Distribuição e diversidade de leguminosae em áreas de Caatinga no Município de Mirandiba - PE. Dissertação de Mestrado, Programa de Pós-Graduação em Biologia Vegetal. Universidade Federal de Pernambuco, Recife, Pernambuco.

Correia C.L.S.B. \& Conceição A.S. (2017) The genus Chamaecrista Moench in a fragment of the Ecological Station Raso da Catarina, Bahia, Brazil. Biota Neotropica, 17(2): 1-15.

Dantas M.M. \& Silva M.J. (2013) O gênero Senna Mill. (Leguminosae, Caesalpinioideae, Cassieae) no Parque Estadual da Serra Dourada, GO, Brasil. Hoehnea, 40(1): 99-113.

Feitosa A.A.F.M.A. (2000) Estudo da percepção dos diferentes grupos ligados ao Parque Ecológico De Engenheiro Ávidos, no Município de Cajazeiras-PB. Dissertação de Mestrado, Programa de Pós-Graduação em Desenvolvimento e Meio Ambiente. Universidade Federal da Paraíba, João Pessoa. Paraíba.

Feitosa A.A.F.M.A., Watanabe T. \& Menezes M.A. (2002) Unidades de conservação no semiárido nordestino: O caso do Parque Ecológico de Engenheiro Ávidos - PB. Raízes, 21(1): 101-113.

Flora do Brasil 2020 em construção. Jardim Botânico do Rio de Janeiro. Disponível em http://floradobrasil.jbrj.gov.br/reflora/floradobrasil/FB115 (acesso em 08/06/2018).

Freitas M.I.A. (2012) Sub-bacia do Alto Piranhas, Sertão Paraibano: Percepção Ambiental e perspectivas na gestão dos recursos hídricos. Dissertação de Mestrado, Programa de PósGraduação em Desenvolvimento e Meio Ambiente. Universidade Federal da Paraíba, João Pessoa, Paraíba.

Gadelha-Neto P.C., Lima J.R., Barbosa M.R.V., Barbosa M.A., Menezes M., Pôrto K.C., Wartchow F. \& Gibertoni T.B. (2013) Manual de Procedimentos para Herbários. Recife: Editora Universitária da UFPE. 53 p.

Gonçalves E.G. \& Lorenzi H J. (2011) Morfologia vegetal: organografia e dicionário ilustrado de morfologia das plantas vasculares. $2^{\mathrm{a}}$ edição. São Paulo: Instituto Plantarum de Estudos da Flora. 512 p.

Irwin H.S. \& Barneby R.C. (1982) The American Cassiinaea synoptical revision of Leguminosae tribe Cassieae subtribe Cassiinae in the New World. Memoirs of the New York Botanical Garden, 35: 1-918.

LPWG (The Legume Phylogeny Working Group) (2013) Legume phylogeny and classification in the 21st century: progress, prospects and lessons for other species-rich clades. Taxon, 62(2): 217-248.

LPWG (The Legume Phylogeny Working Group) (2017) A new subfamily classification of the Leguminosae based on a taxonomically comprehensive phylogeny The Legume Phylogeny Working Group (LPWG). Taxon, 66(1): 44-77.

Lewis G.P., Schrire B.D., Mackinder B.A. \& Lock J.M. (2005) Legumes of the World. Richmond, U.K.: Royal Botanic Gardens, Kew. 577 p. 
Queiroz L.P. (2009) Leguminosas da Caatinga. Universidade Estadual de Feira de Santana/ Royal Botanic Gardens Kew/ Associação Plantas do Nordeste, Feira de Santana. 913 p.

Queiroz R.T. \& Loiola M.I.B. (2009) O gênero Chamaecrista Moench (Caesalpinioideae) em áreas do entorno do Parque Estadual das Dunas de Natal, Rio Grande do Norte, Brasil. Hoehnea, 36(4): 725-736.

Rodrigues R.S., Flores A.S., Miotto S.T.S. \& Baptista L.R.M. (2005) The genus Senna (Leguminosae, Caesalpinioideae) in Rio Grande do Sul State, Brazil. Acta Botanica Brasilica, 19(1): 1-16.

Santos J.P., Souza A.O. \& Silva M.J. (2017) Taxonomia e diversidade do gênero Senna Mill. (Leguminosae, Caesalpinioideae, Cassieae) no estado de Goiás, Brasil. Iheringia, 72(1): 75105.

Silva S.A.L. \& Melo J.I.M. (2013) A família Leguminosae Juss. em dois afloramentos rochosos no município de Puxinanã, Paraíba. Biotemas, 26(4): 23-43.

Souza V.C., Lorenzi H. \& Flores T.B. (2013) Introdução à Botânica: morfologia. São Paulo: Instituto Plantarum de Estudos da Flora. 223 p.

Souza A.O. \& Silva M.J. (2015) Estudo taxonômico do gênero Chamaecrista Moench. (Caesalpinioideae, Leguminosae) na Floresta Nacional de Silvânia, Goiás, Brasil. Iheringia, 70(1): 73-88.

Souza A.O. \& Silva M.J. (2016) Senna (Leguminosae, Caesalpinioideae) in the National Forest Silvânia, Goiás, Brazil. Rodriguésia, 67(3): 773-784.

Spjut R.W. (1994) A systematic treatment of fruit types, vol. 70. New York: New York Botanical Garden. 94 p.

Vidal W.N. \& Vidal M.R.R. (2003) Botânica-Organografía Quadros Sinóticos Ilustrados de Fanerógamos. $4^{\mathrm{a}}$ edição. Viçosa: UFV. 124 p. 